\title{
Metalloproteinases and Spontaneous Coronary Artery Dissection Relationships: A Systematic Review
}

Sofia Braile Sabino ${ }^{1}$, Giovanni Braile Sternieri ${ }^{1}$, Maria Christiane Valéria Braga Braile-Sternieri ${ }^{1}$, Eliana Migliorini Mustafa ${ }^{1}$, Victor Rodrigues Ribeiro Ferreira ${ }^{1}$, Lúcia Angélica Buffulin de Faria ${ }^{1}$, Bethina Cnaroli Sbardellini ${ }^{1}$, Cibele Olegário Vianna Queiroz ${ }^{1}$, Domingo Marcolino Braile ${ }^{1}$, Ana Valéria Garcia Ramirez ${ }^{2}$, Idiberto José Zotarelli Filho $^{1,3^{*}}$, Marinônio Lopes Cornélio ${ }^{3}$

\footnotetext{
${ }^{1}$ Domingo Braile Institute of Sao Jose do Rio Preto, Rua Luiz Vaz de Camoes, 3111 - Vila Redentora, Sao Jose do Rio Preto - SP, 15015-750, Brazil;

${ }^{2}$ Associação Brasileira de Nutrologia (ABRAN)/Brazilian Association of Nutrology, Rua Belo Horizonte, 909-Centro, Catanduva - SP, 15801-150, Brazil;

${ }^{3}$ São Paulo State University (Unesp), Institute of Biosciences, Humanities and Exact Sciences (Ibilce), Campus São José do Rio Preto, São José do Rio Preto - SP, 15054-000, Brazil.
}

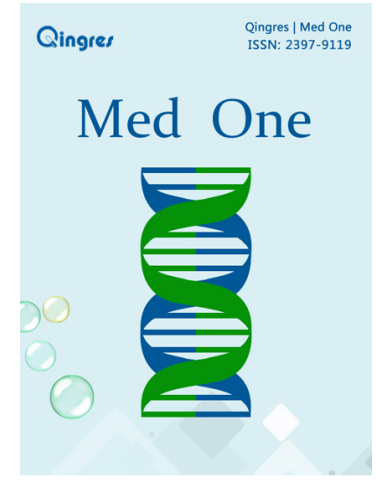

http://mo.qingres.com

\section{GOPEN ACCESS}

DOI: $10.20900 / \mathrm{mo} .20180005$

Received: March 26, 2018

Accepted: June 26, 2018

Published: June 30, 2018

Copyright: ๑ 2018 The Authors. Published by Qingres. This is an open access article distributed under the terms of the Creative Commons Attribution License, which permits unrestricted use, distribution, and reproduction in any medium, provided the original author and source are credited.
*Corresponding Author: Idiberto José Zotarelli Filho, E-mail: scientific@ institutodomingobraile.com.br.

\section{ABSTRACT}

Background: Spontaneous coronary artery dissection (SCAD) may predict fibromuscular dysplasia (FD) in lean Caucasian women, aged $15-50$, with no prior history. There is a marked predominance in females with 75.0 to $100.0 \%$ of the cases.

Objective: This study undertook a meta-analysis of matrix metalloproteinases 2 and 9 actions and inhibitions in the context of fibromuscular dysplasia and subsequent spontaneous coronary artery dissection.

Methods: The literary search criteria used the Mesh Terms cited in the "Search strategies" section. One hundred and four papers submitted for eligibility analysis were collated, twenty-six studies were selected. The review protocol was based on the criteria of literary search with the use of mesh terms in the main databases such as Pubmed, Medline, Bireme, EBSCO, and Scielo.

Conclusion: The patient was diagnosed with this pathology based on a prior acute myocardial infarction and the presence of coronary 
tortuosity which are SCAD predictors. Posttreatment as described below, the patient remained asymptomatic.

Keywords: metalloproteinases; dysplasia fibromuscular; clinical trial spontaneous coronary artery dissection

\section{INTRODUCTION}

Spontaneous coronary artery dissection (SCAD) may be a predictor of fibromuscular dysplasia (FD) ${ }^{[1,2]}$ affecting lean, Caucasian women, aged $15-50$, with no history ${ }^{[3]}$. There is a marked predominance in females who constituted 75.0 to $100.0 \%$ of all cases. The average age being $30-55^{[3]}$. Some studies have also identified this lesion in older postmenopausal women ${ }^{[4-6]}$.

SCAD is a non-traumatic event generated by coronary artery wall segmentation which creates a false lumen ${ }^{[1,2,7]}$. It infrequently causes acute coronary syndrome (unstable angina) and sudden death. Its pathological mechanism is poorly understood. SCAD is only known to associate with the vascular system, inflammatory processes, and vasculopathies, with fibromuscular dysplasia (FD) being the primary main one. Arterial and vein tortuosity being the main morphological sign ${ }^{[2]}$.

FD pathogenesis of can result from elastic fiber fragmentation resulting from degrading by matrix metalloproteinases 2 and 9 (MMP2, MMP9) ${ }^{[7]}$. The MMP roles and inhibitors in FD pathogenesis remains unexplored. More clinical studies are needed to better understand the relationships of these enzymes and how coronary and other vessels are involved ${ }^{[7,8]}$.

The main predictors of this enzymatic breakdown are postpartum, multiparity, tissue disorder, hormone therapies (use of contraception), certain illicit drugs, physical, and emotional, stress. To a lesser degree it associates with syndromes such as Marfan, Ehlers-Danlos, and Horner ${ }^{[9-12]}$.

The MMP pathophysiological control mechanism is unclear. Any decision to treat SCAD invasively, or non-invasively, follows an analysis of clinical and angiographic factors including dissection site, number of vessels affected, and hemodynamics ${ }^{[3]}$. Coronary angioplasty with stent implantation may restore flow, alleviate symptoms, and treat dissection. It has a $65 \%$ success rate. Coronary artery bypass surgery is reserved for multivessel SCAD and trunk dissection. There are no studies evaluating long-term drug treatment ${ }^{[3]}$.

The present study meta-analyzed the action and inhibition of matrix metalloproteinases 2 and 9 in the context of fibromuscular dysplasia and subsequent spontaneous coronary artery dissection.

\section{METHODS}

\subsection{Study design}

One hundred and four papers were collated after being selected by using as the literature search criteria the "Mesh Terms" identified in "Search Strategies". Twenty-six studies were examined following the rules of systematic review-PRISMA (Transparent reporting of systematic reviews and meta-analyzes: http: //www.prisma-statement.org/), as shown in Fig. 1.

\subsection{Eligibility criteria and selection of studies}

Patient inclusion criteria were: (1) either gender; (2) 18 and older; (3) diagnosed with spontaneous coronary dissection; (4) had undergone a noncardiac surgical procedure; (5) presented with acute coronary syndromes intraoperatively or postoperatively (up to 30 post-intervention); (6) unstable angina as defined by chest pain or ischemic equivalent (pulmonary congestion, cardiogenic shock) at rest and compatible electrocardiographic changes (ST segment depression of at least $0.05 \mathrm{mV}$ or T wave inversion); (7) "acute myocardial infarction" defined as elevation and decrease of myocardial necrosis markers: troponin T or I or CKMB mass associated with ischemic symptoms or associated with electrocardiographic changes compatible with ischemia: changes of the ST segment or T wave or $Q$ wave appearance.

Exclusion criteria were those who had not undergone coronary angiography or patients with SCAD who did not otherwise meet the inclusion criteria, such as patients with unstable angina, but no electrocardiographic abnormalities.

\subsection{Sources of information}

The review protocol was based on the literature search criteria using mesh terms in the main databases such as Pubmed, Medline, Bireme, EBSCO, and Scielo. All references are registered in EndNote at site:

http://www.myendnoteweb.com/EndNoteWeb. html?cat=myrefs \&. 


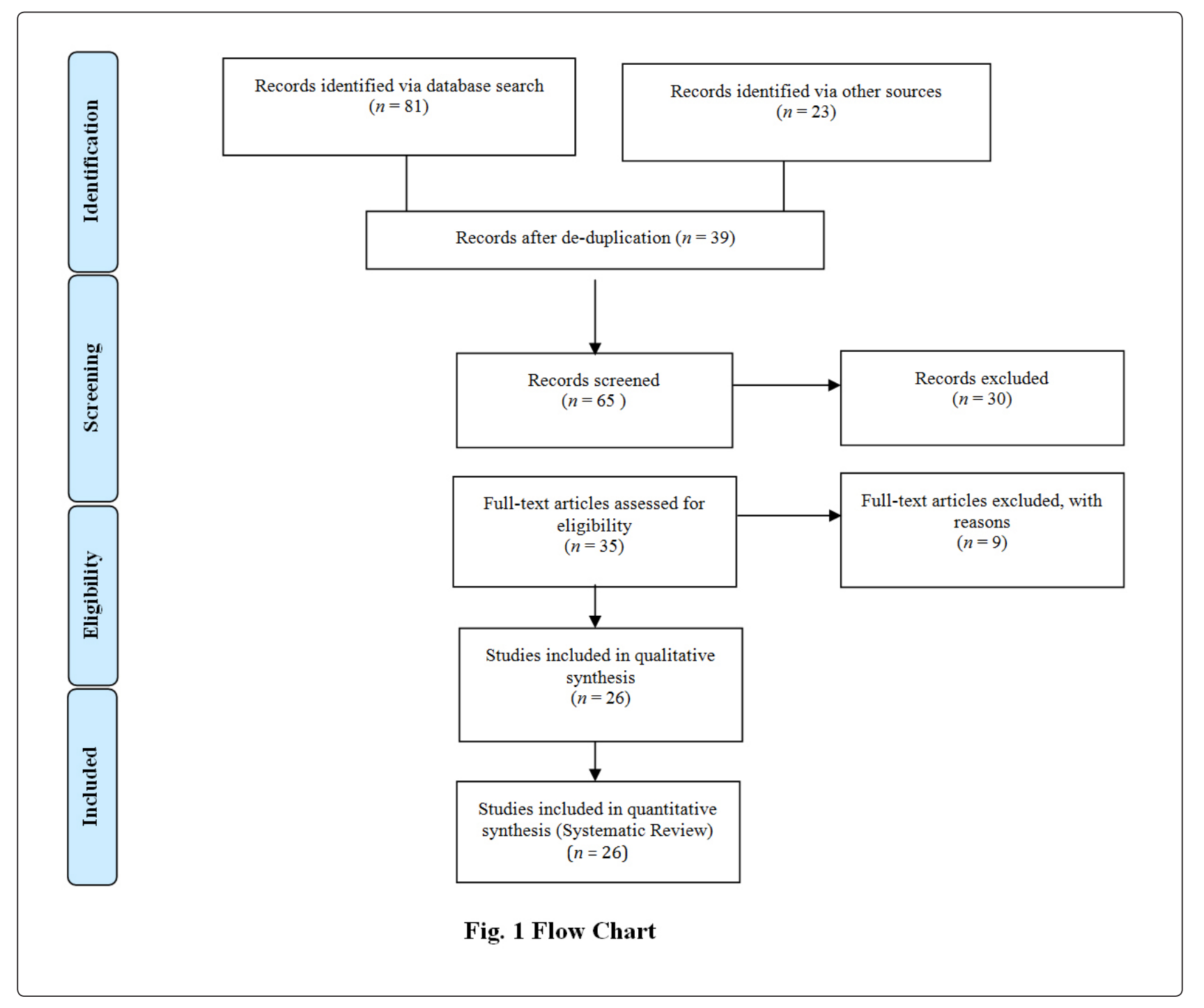

\subsection{Search strategy}

An example of a search strategies appear in MEDLINE/Pubmed, Web Of Science, ScienceDirect Journals (Elsevier), Scopus (Elsevier), and OneFile (Gale) and followed these steps: - search for mesh terms (Metalloproteinases, dysplasia fibromuscular, clinical trial Spontaneous Coronary Artery Dissection), use of the bouleanos "and" between mesh terms and "or" among historical findings.

\subsection{Statistical treatment of literary findings}

A descriptive analysis was performed using standard parameters for mean, standard deviation, and amplitude. An Anderson-Darling normality test ( $\alpha$-level > 0.10 considered "normal") was performed for continuous and categorical data, with a subsequent application of a Kruskal-Wallis analysis of variance to the internal data for each study alone, and deeming a $p$-value of less than 0.05 as statistically significant. An equivalence test $\left(\mathrm{I}^{2}\right)$ between the data of each work was also performed.

\subsection{Literature review and discussion}

The metanalysis provided information about spontaneous coronary artery dissection as a rare, though potentially fatal ( $50 \%$ sudden death) cause of acute myocardial infarction with estimated cineangiography incidence between $0.04 \%$ and $0.20 \%{ }^{[13]}$. There were no statistical differences between the studies. The equivalence level between the study results was $93.5 \%$. (Table 1 ) 
Table 1. Primary literature findings for MMP action in fibromuscular dysplasia and statistical treatment of the results deeming $p<0.05$ statistically different

\begin{tabular}{|c|c|c|c|c|c|}
\hline Authors/Data & Year & Study type & Key findings & $p$-value & References \\
\hline $\begin{array}{l}\text { Tscheuschler } \\
\text { et al. }\end{array}$ & 2016 & Prospective & $\begin{array}{l}\text { MMP-2 Isoforms in Aortic Tissue and } \\
\text { Serum of Patients }\end{array}$ & $>0.05$ & [1] \\
\hline Liu et al. & 2016 & Prospective & $\begin{array}{l}\text { MMP-2 gene polymorphisms are } \\
\text { associated with type A aortic dissection }\end{array}$ & $>0.05$ & [2] \\
\hline $\begin{array}{l}\text { Albuquerque } \\
\text { et al. }\end{array}$ & 2014 & Review & Spontaneous Coronary Artery Dissection & $>0.05$ & [3] \\
\hline $\begin{array}{l}\text { Kadian-Dodov } \\
\text { et al. }\end{array}$ & 2016 & Prospective & $\begin{array}{l}\text { Dissection and Aneurysm in Patients With } \\
\text { Fibromuscular Dysplasia }\end{array}$ & $>0.05$ & [4] \\
\hline Kiando et al. & 2016 & Prospective & $\begin{array}{l}\text { Is a Genetic Susceptibility Locus for } \\
\text { Fibromuscular Dysplasia }\end{array}$ & $>0.05$ & {$[5]$} \\
\hline Tweet et al. & 2012 & Review & $\begin{array}{l}\text { Clinical features, management and } \\
\text { prognosis of spontaneous coronary } \\
\text { artery dissection }\end{array}$ & $>0.05$ & [6] \\
\hline Werner et al. & 2016 & $\begin{array}{l}\text { Systematic } \\
\text { review }\end{array}$ & $\begin{array}{l}\text { The role of extracellular and intracellular } \\
\text { proteolytic systems in aneurysms of the } \\
\text { ascending aorta. }\end{array}$ & $>0.05$ & [7] \\
\hline Zhang et al. & 2014 & $\begin{array}{l}\text { Controlled } \\
\text { prospective }\end{array}$ & Levels in chronic thoracic aortic dissection. & $>0.05$ & [8] \\
\hline Paltseva et al. & 2016 & $\begin{array}{l}\text { Controlled } \\
\text { prospective }\end{array}$ & $\begin{array}{l}\text { Expression of matrix metalloproteinases } \\
\text { and their inhibitors in the internal } \\
\text { carotid artery }\end{array}$ & $>0.05$ & [9] \\
\hline Paltseva et al. & 2015 & $\begin{array}{l}\text { Controlled } \\
\text { prospective }\end{array}$ & $\begin{array}{l}\text { The structure of the internal carotid } \\
\text { artery wall }\end{array}$ & $>0.05$ & [10] \\
\hline $\begin{array}{l}\text { Stepanenko } \\
\text { et al. }\end{array}$ & 2015 & Review & $\begin{array}{l}\text { Surgical treatment for } \\
\text { fibromuscular dysplasia }\end{array}$ & $>0.05$ & {$[11]$} \\
\hline Mclnnis et al. & 2016 & Case report & $\begin{array}{l}\text { Horner syndrome in } \\
\text { fibromuscular dysplasia }\end{array}$ & $>0.05$ & [12] \\
\hline Andrade et al. & 2010 & Case report & $\begin{array}{l}\text { Acute Myocardial Infarction as } \\
\text { Presentation of Spontaneous Coronary } \\
\text { Artery Dissection. }\end{array}$ & $>0.05$ & [13] \\
\hline Barbosa et al. & 2013 & Case series & $\begin{array}{l}\text { Acute Myocardial Infarction by } \\
\text { Spontaneous Coronary Artery Dissection }\end{array}$ & $>0.05$ & [14] \\
\hline Manhaes et al. & 2014 & Case series & Spontaneous Coronary Artery Dissection & $>0.05$ & {$[15]$} \\
\hline Haussen et al. & 2016 & Case report & $\begin{array}{l}\text { Internal Carotid Artery S-Shaped Curve } \\
\text { as a Marker of Fibromuscular Dysplasia }\end{array}$ & $>0.05$ & [16] \\
\hline Pontes et al. & 2011 & $\begin{array}{l}\text { Systematic } \\
\text { review }\end{array}$ & $\begin{array}{l}\text { Displasia fi bromuscular: um } \\
\text { diagnóstico diferencial }\end{array}$ & $>0.05$ & [17] \\
\hline
\end{tabular}


Joux et al. $2016 \quad$ Prospective

Toggweiler

et al.

2012 Prospective

Olin et al.

2011 Review

Saw et al.

2013 Retrospective

Hendricks

et al.

2014 Clinical trial

Persu et al.

2014

European consensus

Kiando et al.

2015 Retrospective

Debette et al.

2015 Retrospective

Prasad et al.

2015

Retrospective
MRI characteristics of carotid bulb

atypical fibromuscular dysplasia in black $\quad>0.05$ stroke patients

Associated vascular lesions in

patients with spontaneous coronary $\quad>0.05$

artery dissection

Diagnosis, management, and future

developments of fibromuscular dysplasia

$>0.05$

[20]

Spontaneous coronary artery dissection:

prevalence of predisposing conditions $\quad>0.05$

including fibromuscular dysplasia

Is fibromuscular dysplasia

underdiagnosed?

$>0.05$

[22]

European consensus on the diagnosis and management of fibromuscular dysplasia.

$>0.05$

Exome sequencing in seven families and gene-based association studies indicate

genetic heterogeneity and suggest $\quad>0.05$

possible candidates for fibromuscular

dysplasia.

Common variation in PHACTR1 is

associated with susceptibility to cervical $\quad>0.05$ artery dissection.

Prevalence of extracoronary vascular abnormalities and fibromuscular dysplasia in patients with spontaneous coronary $>0.05$ artery dissection

Equivalent Test I $^{2}$

$93.5 \%$

The anterior descending coronary artery is the vessel most affected by SCAD. It has a prevalence of $40-60 \%$. It is followed by the circumflex artery and its branches $(30 \%)$, primarily the medial and distal segments ${ }^{[14]}$. The disease may associate with a genetic component as it mostly affects Caucasians with an HLA-DR6 histocompatibility antigen ${ }^{[17]}$.

Pro-MMP-2 was present in all tissue, and serum, samples of all patients with ascending aortic/ aortic root aneurysms ${ }^{[1]}$. Active MMP-2 species are not released into the circulatory system or are undetectable in serum. There is no reliable connection between MMP-2 isoforms in aortic tissue and serum. Nor is there any indication that pro-MMP-2 functions as a major aortic wall stress common marker ${ }^{[1]}$.
MMP-2 plays an important role in the pathogenesis of type $A$ aortic dissection (AD). One study analyzed the association of 3 single nucleotide polymorphisms in the MMP-2 gene with risk of type A (AD) and aortic diameters. MMP-2 polymorphisms contributed to type A susceptibility. MMP-2 gene nucleotides associate with AD size which could be targeted for new drug therapies ${ }^{[2]}$. MMP tissue inhibitor imbalances, the TIMPs may lead to aortic wall failure. Total MMP-1, total MMP-9, and active MMP-9 levels were higher and total MMP-2 levels were lower in dissection tissue than in control tissue. The ratio of MMP-9 to TIMP-1 and the ratio of active to total MMP-2 were higher. The ratio of MMP-2 to TIMP-2 was lower in dissection tissue. Patients had a higher ratios of plasma-active to 
total MMP-9 than controls ${ }^{[8]}$. Age and hypertension associated with increased MMP levels. Several MMPs increased levels and increased MMP-to-TIMP ratios in aortic tissue suggested an environmentfavoring proteolysis. This may promote progressive extracellular matrix destruction and medial degeneration after aortic dissection. An elevated active-to-total MMP-9 ratio in plasma may be a biomarker for end-stage aneurysm in patients with chronic thoracic aortic disease ${ }^{[8]}$.

SCAD, at the molecular level, may be related to MMP expression and consequent elastin degradation ${ }^{[5]}$. Elastic fiber fragmentation in coronary arteries is due to an imbalance between metalloproteinase 2 (MMP2) and metalloproteinase 9 (MMP9) on its inhibitor TIMP1 and TIMP2 ${ }^{[5]}$. This may be the primary pathological cause and enzymatic homeostasis during treatment. Future studies of MMP effect as a SCAD predictor could be one such approach.

The presence of a common variant, rs9349379, located on chromosome 6 of the phosphatase and actin-regulator gene 1 (PHACTR1), has been shown to increase foot-and-mouth disease (FMD) risk by about $40 \%{ }^{[5]}$. rs9349379 correlates with PHACTR1 expression in fibroblasts of patients with FMD and controls. The presence of this allele also increases FD risk and is present with cervical artery dissection and migraine risk. It is often reported in FD patients. The PHACTR1 role in maintaining vascular vessel integrity is not fully understood ${ }^{[5,24-26]}$.

Generally, diagnosis is performed by "catheterism". An intramural hematoma is difficult to detect visually. Diagnoses may be imprecise. Other diagnostic technologies, such as coronary computed tomography and intravascular ultrasound are used. Symptomatology depends on which coronaries vessels suffered dissection and how dissected they are. Patients may present asymptomatic ${ }^{[2,3]}$.

Half of the survivors had survival rates of approximately $80.0 \%$ at 30 months. Half developed a second dissection within two months ${ }^{[13]}$. Women had lower survival rates than men particularly when the event occurred outside peripartum ${ }^{[13]}$.

Some studies have tested the hypothesis of a relationship between SCAD and the presence of FD in other arterial sites. Some researchers performed whole-body angio-CT and angio-MRI on SCAD patients on three with cases of renal FD ${ }^{[3,19]}$. Low FD incidence is related to poor imaging method sensitivity which detects stenosis in less than $50.0 \%$ of the middle and distal arterial segments ${ }^{[3]}$.

A $50.0 \%$ prevalence of FD in the external iliac artery of 16 patients with SCAD undergoing iliofemoral angiography was found in one study ${ }^{[6]}$. Another found $86 \%$ of 50 patients with SCAD had with FD ${ }^{[21]}$. A study of family members of SCAD patients found that only $7.0 \%$ did.

A study of 144 patients reported on treatment and follow-up for fibromuscular dysplasia ${ }^{[11]}$. Postcarotid surgery follow-up did not show cardiac arrest, stenosis, or death. Persistent normalization of blood pressure was achieved in 11 (73.3\%) cases. Surgical treatment with some forms of FD provides satisfactory results if the recommended strategy is followed ${ }^{[11]}$.

Between 2008 and 2010,5 patients hospitalized with acute coronary syndrome, as evidenced via coronary angiography, suffered spontaneous coronary dissection. Intracoronary ultrasonography was useful in diagnosing spontaneous coronary dissection and in guiding percutaneous treatment ${ }^{[14,26]}$.

A retrospective unicentric study provided corroboration by identifying 25 patients with spontaneous coronary artery dissection, $56.0 \%$ of whom were females, aged $48.8 \pm 10$. In $92.0 \%$ of the cases, acute coronary syndrome was present. A conservative strategy was performed in $56 \%$, percutaneous coronary intervention in $40 \%$, and myocardial revascularization in $4 \%$, of the cases. The existence of a variety of therapeutic strategies confirms the still-unsettled opinion as to the ideal approach to spontaneous coronary artery dissection and an emphasis on individualized treatment ${ }^{[15,22,23]}$.

\section{CONCLUSION}

The patient was diagnosed with this pathology due to a prior episode of acute myocardial infarction and the presence of coronary tortuosity, which are SCAD predictors. After being treated as described above, the patient remained asymptomatic.

We intend a follow-up study of MMPs as predictors of spontaneous coronary artery dissection.

\section{AUTHOR CONTRIBUTIONS}

- Idiberto José Zotarelli Filho conceived of the presented idea.

- Sofia Braile Sabino, Giovanni Braile Sternieri and Maria Christiane Valéria Braga BraileSternieri developed the theory and performed the computations. 
- Eliana Migliorini Mustafa, Victor Rodrigues Ribeiro Ferreira, Lúcia Angélica Buffulin de Faria verified the analytical methods.

- Bethina Canaroli Sbardellini, Cibele Olegário Vianna Queiroz, Domingo Marcolino Braile encouraged Ana Valéria Garcia Ramirez and Marinônio Lopes Cornélio to investigate and supervised the findings of this work and to make the review process after the suggestions of the reviewers.

- All authors discussed the results and contributed to the final manuscript.

\section{REFERENCES}

1. Tscheuschler A, Meffert P, Beyersdorf F, Heilmann C, Kocher N, Uffelmann X, Discher P, Siepe M, Kari FA. MMP-2 Isoforms in Aortic Tissue and Serum of Patients with Ascending Aortic Aneurysms and Aortic Root Aneurysms. PLoS One. 2016; 11(11): e0164308.

2. Liu O, Xie W, Qin Y, Jia L, Zhang J, Xin Y, Guan $X$, Li H, Gong M, Liu Y, Wang X, Li J, Lan F, Zhang $\mathrm{H}$. MMP-2 gene polymorphisms are associated with type A aortic dissection and aortic diameters in patients. Medicine (Baltimore). 2016; 95(42): e5175.

3. Albuquerque CED, Nani E, Martins WA, Souza ALS. Spontaneous Coronary Artery Dissection. Rev Bras Cardiol. 2014; 27(5): 370-373.

4. Kadian-Dodov D, Gornik HL, Gu X, Froehlich J, Bacharach JM, Yung-Wei Chi, DO, Gray $\mathrm{BH}$, Jaff MR, Kim ESH, Mace P, Sharma A, Kline-Rogers E, White C, Olin JW. Dissection and Aneurysm in Patients With Fibromuscular Dysplasia: Findings From the U.S. Registry for FMD. J Am Coll Cardiol. 2016; 68(2): 176-185.

5. Kiando SR, Tucker NR, Castro-Vega LJ, Katz A, D'Escamard V, Tréard C, Fraher D, Albuisson J, Kadian-Dodov D, Ye Z, Austin E, Yang ML, Hunker K, Barlassina C, Cusi D, Galan P, Empana JP, Jouven X, Gimenez-Roqueplo AP, Bruneval P, Hyun Kim ES, Olin JW, Gornik HL, Azizi M, Plouin PF, Ellinor PT, Kullo IJ, Milan DJ, Ganesh SK, Boutouyrie P, Kovacic JC, Jeunemaitre X, Bouatia-Naji N. PHACTR1 Is a Genetic Susceptibility Locus for Fibromuscular Dysplasia Supporting Its Complex Genetic Pattern of Inheritance. PLoS Genet. 2016; 12(10): e1006367.

\section{ACKNOWLEDGEMENTS}

The work was supported by Domingo Braile Institute - São José do Rio Preto - SP, Brazil.

\section{DECLARATION OF POTENTIAL CONFLICT OF INTEREST}

The authors declare no conflicts of interest.

6. Tweet MS, Hayes SN, Pitta SR, Simari RD, Lerman A, Lennon RJ, Gersh BJ, Khambatta S, Best PJ, Rihal CS, Gulati R. Clinical features, management and prognosis of spontaneous coronary artery dissection. Circulation. 2012; 126(5): 579-588.

7. Werner I, Schack S, Richter M, Stock UA, Ahmad Ael-S, Moritz A, Beiras-Fernandez A. The role of extracellular and intracellular proteolytic systems in aneurysms of the ascending aorta. Histol Histopathol. 2016; 31(5): 523-534.

8. Zhang $X$, Wu D, Choi JC, Minard CG, Hou X, Coselli JS, Shen YH, LeMaire SA. Matrix metalloproteinase levels in chronic thoracic aortic dissection. J Surg Res. 2014; 189(2): 348-358.

9. Paltseva EM, Polyakova VO, Oskolkova SA, Abramyan AV, Ivanova AG, Krylova YS, Gavrilenko AV. Expression of matrix metalloproteinases and their inhibitors in the internal carotid artery wall in pathological tortuosity. Arkh Patol. 2016; 78(3): 26-31.

10. Paltseva EM, Oskolkova SA, Polyakova VO, Krylova YS, Ivanova AG, Abramyan AV, Gavrilenko AV. The structure of the internal carotid artery wall in pathological tortuosity. Arkh Patol. 2015; 77(5): 3-8.

11. Stepanenko AB, Charchyan ER, Gens AP, Fedorov DN, Ivanova AG, Vysotskiy MV, Belov YV. Surgical treatment for fibromuscular dysplasia. Khirurgiia (Mosk). 2015; (9): 21-27.

12. McInnis CP, Haynor DR, Francis CE. Horner syndrome in fibromuscular dysplasia without carotid dissection. Can J Ophthalmol. 2016; 


\section{1: 49-53.}

13. Andrade HA, Feijó LA, Lavall GC, Tedeschi AL. Acute Myocardial Infarction as Presentation of Spontaneous Coronary Artery Dissection. Rev Bras Cardiol. 2010; 23(2): 251-254.

14. Barbosa RR, Rinaldi FS, Ribamar JC Jr, Feres F, Abizaid A, Sousa AG, Sousa JE. Infarto Agudo do Miocárdio por Dissecção Espontânea de Artérias Coronárias Série de Cinco Casos. Rev Bras Cardiol Invasiva. 2013; 21(2): 193-198.

15. Manhaes EB, Gomes WF, Bezerra CG, Horta PE, Gama MN, Cesar LA, Perin MA, Silva EE, Caixeta A, Cade J, Neto PA. Dissecção Espontânea de Artéria Coronária: Abordagem Terapêutica e Desfechos de Uma Série Consecutiva de Casos. Rev Bras Cardiol Invasiva. 2014; 22(1): 32-35.

16. Haussen DC, Jadhav A, Rebello LC, Belagaje S, Anderson A, Jovin T, Aghaebrahim A, Gulati D, Wells B, Frankel M, Nogueira RG. Internal Carotid Artery S-Shaped Curve as a Marker of Fibromuscular Dysplasia in Dissection-Related Acute Ischemic Stroke. Intervent Neurol. 2016; 5: 185-192.

17. Pontes TC, Rufino GP, Gurgel MG, Medeiros AC, Freire EA. Displasia fi bromuscular: um diagnóstico diferencial para as vasculitis. Rev Bras Reumatol. 2011; 52(1): 66-74.

18. Joux J , Mejdoubi M, Quere JB , Colombani S , Hennequin JL, Deschamps L, Jeannin S, Olindo S. MRI characteristics of carotid bulb atypical fibromuscular dysplasia in black stroke patients. J Neuroradiol. 2016; 43(3): 214-217.

19. Toggweiler S, Puck M, Thalhammer C, Manka R, Wyss M, Bilecen D, Corti R, Amann-Vesti BR, Lüscher TF, Wyss CA. Associated vascular lesions in patients with spontaneous coronary artery dissection. Swiss Med Wkly. 2012; 142: 13538.

20. Olin JW, Sealove BA. Diagnosis, management, and future developments of fibromuscular dysplasia. J Vasc Surg. 2011; 53: 826-836.

21. Saw J, Ricci D, Starovoytov A, Fox R, Buller CE. Spontaneous coronary artery dissection: prevalence of predisposing conditions including fibromuscular dysplasia in a tertiary center cohort. JACC Cardiovasc Interv. 2013; 6(1): 44-52.
22. Hendricks NJ, Matsumoto $A H$, Angle JF, Baheti A, Sabri SS, Park AW, Stone JR, Patrie JT, Dworkin L, Cooper CJ, Murphy TP, Cutlip DE. Is fibromuscular dysplasia underdiagnosed? A comparison of the prevalence of FMD seen in CORAL trial participants versus a single institution population of renal donor candidates. Vasc Med. 2014; 19: 363-367.

23. Persu A, Giavarini A, Touzé E, Januszewicz A, Sapoval M, Azizi M, Barral X, Jeunemaitre $X$, Morganti A, Plouin PF, de Leeuw P; ESH Working Group Hypertension and the Kidney. European consensus on the diagnosis and management of fibromuscular dysplasia. J Hypertens. 2014; 32: 1367-1378.

24. Kiando SR, Barlassina C, Cusi D, Galan P, Lathrop M, Plouin PF, Jeunemaitre X, BouatiaNaji N. Exome sequencing in seven families and gene-based association studies indicate genetic heterogeneity and suggest possible candidates for fibromuscular dysplasia. J Hypertens. 2015; 33: 1802-1810.

25. Debette S, Kamatani $Y$, Metso TM, Kloss M, Chauhan G, Engelter ST, Pezzini A, Thijs V, Markus HS, Dichgans M, Wolf C, Dittrich R, Touzé E, Southerland AM, Samson Y, Abboud S, Béjot Y, Caso V, Bersano A, Gschwendtner A, Sessa M, Cole J, Lamy C, Medeiros E, Beretta S, Bonati LH, Grau AJ, Michel P, Majersik JJ, Sharma P, Kalashnikova L, Nazarova M, Dobrynina L, Bartels E, Guillon B, van den Herik EG, Fernandez-Cadenas I, Jood K, Nalls MA, De Leeuw FE, Jern C, Cheng YC, Werner, Metso AJ, Lichy C, Lyrer PA, Brandt T, Boncoraglio GB, Wichmann HE, Gieger $C$, Johnson $A D$, Böttcher $T$, Castellano $M$, Arveiler D, Ikram MA, Breteler MM, Padovani A, Meschia JF, Kuhlenbäumer G, Rolfs A, Worrall BB; International Stroke Genetics Consortium, Ringelstein EB, Zelenika D, Tatlisumak T, Lathrop M, Leys D, Amouyel P, Dallongeville J; CADISP Group. Common variation in PHACTR1 is associated with susceptibility to cervical artery dissection. Nat Genet. 2015; 47: 78-83.

26. Prasad M, Tweet MS, Hayes SN, Leng S, Liang JJ, Eleid MF, Gulati R, Vrtiska TJ. Prevalence of extracoronary vascular abnormalities and fibromuscular dysplasia in patients with spontaneous coronary artery dissection. Am J Cardiol. 2015; 115: 1672-1677. 